\title{
Influence of Age and Number of Seedlings on Yield and Nutrient Uptake by Machine Transplanted Rice (Oryza sativa L.)
}

\author{
R. B. Negalur ${ }^{*}$, A. S. Halepyati ${ }^{2}$ and K. Narayana Rao $^{3}$ \\ ${ }^{1}$ AICRP on Weed Management, MARS, UAS, Raichur, Karnataka (583 227), India \\ ${ }^{2}$ Division of Agronomy, ${ }^{3}$ Dept. of Soil Science \& Agril. Chemistry, UAS, Lingasugur Road, Raichur, Karnataka (584 104), India
}

\section{Article History}

Manuscript No. AR1548

Received in $28^{\text {th }}$ February, 2016

Received in revised form $24^{\text {th }}$ May, 2016

Accepted in final form $28^{\text {th }}$ May, 2016

\section{Correspondence to}

*E-mail: tushberkipilli@rediffmail.com

\section{Keywords}

Rice, Seedling age, number, machine transplanting, yield, nutrient.

\begin{abstract}
The field experiments were conducted at Agricultural Research Station, Gangavathi, University of Agricultural Sciences, Raichur, Karnataka during kharif, 2012 and 2013 to study the effect of different age and number of seedlings hill ${ }^{-1}$ on nutrient uptake, availability and yield of machine transplanted rice. Pooled mean indicated that, planting of twenty five days old seedlings recorded significantly higher uptake of nitrogen by grain $\left(68.06 \mathrm{~kg} \mathrm{ha}^{-1}\right)$, straw $\left(47.46 \mathrm{~kg} \mathrm{ha}^{-1}\right)$ and total nitrogen uptake by the plant (115.52 $\left.\mathrm{kg} \mathrm{ha}^{-1}\right)$ uptake of phosphorous by grain $\left(26.06 \mathrm{~kg} \mathrm{ha}^{-1}\right)$, straw $\left(13.20 \mathrm{~kg} \mathrm{ha}^{-1}\right)$ and total phosphorous uptake by the plant $\left(37.26 \mathrm{~kg} \mathrm{ha}^{-1}\right)$, uptake of potash by grain $\left(20.66 \mathrm{~kg} \mathrm{ha}^{-1}\right)$, straw $\left(57.19 \mathrm{~kg} \mathrm{ha}^{-1}\right)$ and total potash uptake by the plant $(77.85 \mathrm{~kg}$ $\left.\mathrm{ha}^{-1}\right)$, available soil nitrogen, phosphorous and potash (236.30, 47.80 and 345.30 $\mathrm{kg} \mathrm{ha}^{-1}$, respectively), grain and straw yield (5101 and $6335 \mathrm{~kg} \mathrm{ha}^{-1}$, respectively), Likewise planting of 3-4 seedlings recorded significantly higher uptake of nitrogen by grain, straw and total nitrogen uptake by the plant $\left(71.67,50.96\right.$ and $122.63 \mathrm{~kg} \mathrm{ha}^{-1}$, respectively), uptake of phosphorous by grain, straw and total phosphorous uptake by the plant $\left(25.31,13.73\right.$ and $39.03 \mathrm{~kg} \mathrm{ha}^{-1}$, respectively), uptake of potash by grain, straw and total potash uptake by the plant $\left(21.78,59.67\right.$ and $81.45 \mathrm{~kg} \mathrm{ha}^{-1}$, respectively), available soil nitrogen, phosphorous and potash $\left(230.95,45.35\right.$ and $342.95 \mathrm{~kg} \mathrm{ha}^{-1}$, respectively), grain and straw yield (5330 and $6585 \mathrm{~kg} \mathrm{ha}^{-1}$, respectively).
\end{abstract}

\section{Introduction}

Rice (Oryza sativa L.) is the major staple food for more than half of the global population. Asian countries consume about $90 \%$ of the rice grown and produced in the world and supplies 50 to $80 \%$ calories of energy to Asians (Anonymous, 2008). Rice is the anchors of food security in the world with challenges of climate change, which is grown under wide range of latitudes and altitudes. The World's total estimated area under rice production is 157.8 mha with a production of $749.8 \mathrm{mt}$ with an average yield of $4752 \mathrm{~kg} \mathrm{ha}^{-1}$ (FAO, 2015). In rice production, India ranks second as it is grown in almost all the states of the country. Total estimated area under rice in India is 42.50 mha with a production of 100.12 million tones with a productivity of $2400 \mathrm{~kg} \mathrm{ha}^{-1}$ (Anonymous, 2015). West Bengal has the highest rice production, while Punjab has the highest productivity of rice among the different rice growing states of India.

Proper age of seedlings for transplanting varies with management practices, growth period, variety and growing season (Uphoff, 2005). Highest values of leaf area index (LAI), number of filled spikelets, thousand seed weight, grain yields and better economic advantage from plants raised from 25 days old seedlings compared to 30 days old seedlings (Tadesse et al., 2013). Twenty days old seedlings were most suitable for transplanters namely QUAT, CRRI and Yanji (Aswini et al., 2009). Seedlings mat characteristics such as seedlings density; mat moisture content and age of seedlings play a major role for efficient performance of the self-propelled rice transplanter. At the same time, the operating speed also influences the performance of the transplanter. However, the performance of paddy transplanter depends on nursery mats with a particular density of seedlings, thickness of mats and seedlings age. Therefore, it is necessary to optimize the age of seedlings for minimizing root damage for proper functioning of the transplanters (Aswini et al., 2009).

Number of seedlings hill-1 is another important factor that it can play an important role in boosting yield of rice as it influences 
the tiller formation, solar radiation interception, total sunshine reception, nutrient uptake, rate of photosynthesis and other physiological phenomena and ultimately affects the growth and development of rice plant (Hossain et al., 2003).

Mechanical transplanting not only facilitates better stand establishment of the rice crop at right time but also allows the genotype to exhibit phenotypic characteristics completely. Therefore, it is high time for mechanizing the transplanting operation in rice cultivation. Mechanical transplanting needs a suitable rice seedlings transplanter. Mechanical transplanter using self-propelled transplanter has been considered as the most promising option because it saves labour to the tune of $90 \%$ of that required in manual transplanting, minimizes stress and drudgery, ensures timely transplanting and attains optimum plant density contributing to higher productivity (Behera, 2000). A well-developed and healthy root system play an important role in uptake and translocation of nutrients from the soil coupled with profuse and robust root system developed due to seedling vigour might have facilitated greater ability of absorption and translocation of major nutrients like $\mathrm{N}, \mathrm{P}$ and $\mathrm{K}$ which in turnhave contributed for higher yield (Naidu et al., 2013).

Transplanting is done manually, which is tough and involves enormous drudgery and human stress in sweltering weather. It requires about 300-350 man-hours ha ${ }^{-1}$, which is approximately $25 \%$ of total labour requirement for paddy cultivation (Singh et al., 1985). Further non availability of labours at peak planting period has compounded the situation and paddy transplanting has emerged as the problem in the major rice growing areas. This results in delay in transplanting and decrease in yield. It is reported that a delay in transplanting by one month reduces the yield by $25 \%$ and a delay of two months reduces the yield by $70 \%$ (Rao and Pradhan, 1973).

\section{Materials and Methods}

A field experiment was conducted at Agricultural Research Station, Gangavathi, University of Agricultural Sciences, Raichur, Karnataka, during kharif, 2012 and 2013. The experiment was laid in strip-plot design. This design facilities for transplanting of different aged and number of seedlings at a stretch in a particular replication. The soil of the experimental site was medium deep black clay (Vertisol) with soil reaction (8.2), electrical conductivity (2.1) determined following the procedure given by Jackson (1973), available N (247.2 kg ha $\left.^{-1}\right)$ Subbaiah and Asija (1956), available $\mathrm{P}_{2} \mathrm{O}_{5}\left(50.2 \mathrm{~kg} \mathrm{ha}^{-1}\right)$ (Olsen et al., 1954) and available $\mathrm{K}_{2} \mathrm{O}\left(357.6 \mathrm{~kg} \mathrm{ha}^{-1}\right)$ Jackson (1973) at surface $0-20 \mathrm{~cm}$ soil depth as majority of the applied nutrients in rice are at this particular range of depth.

Agricultural Research Station, Gangavathi is situated in the
Northen Dry Zone of Karnataka between $15^{\circ} 15^{\prime} 40^{\prime \prime}$ North latitude and 76 $31^{\prime} 40^{\prime \prime}$ East longitude at an altitude of 419 $\mathrm{m}$ above mean sea level and represents irrigated transplanted rice belt of Tungabhadra command area. The experiment consisted three different age of seedlings viz., $\mathrm{A}_{1:}$ twenty days old seedlings, $\mathrm{A}_{2}$ : twenty five days old seedlings and $\mathrm{A}_{3}$ : thirty days old seedlings (below twenty days are young and tender, which will be prone to mechanical damage by force of fingers of transplanter) and three different number of seedlings hill ${ }^{-1}$ planted by transplanter viz., $\mathrm{N}_{1}: 3-4$ seedlings hill ${ }^{-1}, \mathrm{~N}_{2}: 5-6$ seedlings hill ${ }^{-1}$ and $\mathrm{N}_{3}: 7-8$ seedlings hill ${ }^{-1}$. (The particular transplanting machine (KUBOTA Model NSPU-68C) was not having the facility of picking 2-3 seedlings). The land was prepared using tractor drawn cultivator twice, followed by puddling twice with disc puddler and finally levelled using tractor drawn spike tooth harrow and kept ready for planting and the seedlings raised as per the seedling age treatments were planted on the same day. Six days after transplanting, butachlor $50 \mathrm{EC}$ at the rate of 2.5 liter ha ${ }^{-1}$ was sand mixed and broadcasted uniformly over the field containing a thin film of water followed by two hand weedings at 20 and 40 days after transplanting. Recommended dose of fertilizers (150:75:75 and $20 \mathrm{~kg} \mathrm{~N}: \mathrm{P}_{2} \mathrm{O}_{5}: \mathrm{K}_{2} \mathrm{O}$ and $\mathrm{ZnSO}_{4}$ ha $^{-1}$ ) were applied as per the recommendation and time. The crop was harvested at physiological maturity, threshed and cleaned manually in both the years. Both grain and straw were sun dried for a week and dry weights were recorded.

Nitrogen, phosphorus and potassium content in plant sample of rice at harvest was estimated by modified micro-kjeldhal method, vanadomolybdate yellow colour method and flame photometer method, respectively as outlined by Jackson, (1967). Nutrient uptake was calculated by using the following formula,

Nutrient uptake $\left(\mathrm{kg} \mathrm{ha}^{-1}\right)=\frac{\text { Nutrient content }(\%)}{100} \times$ dry wt $\left(\mathrm{kg} \mathrm{ha}^{-1}\right)$

\section{Results and Discussion}

\subsection{Grain and straw yield}

\subsubsection{Age of seedlings}

Age of seedlings had significant influence on yield attributes and yield. The higher number of panicles $\left(378.22 \mathrm{~m}^{2}\right)$, number of grains panicle $\mathrm{e}^{-1}(5.68 \%)$, number of grain filling \% (3.94), test weight $(6.40 \%)$, grain yield $(6.25 \%)$ and straw yield (5.67\%) was also noticed by planting of twenty-five days old seedlings over planting of twenty days old seedlings (Table 1). This treatment was followed by planting of thirty days old seedlings. (Kim et al., 1999) reported that young seedlings had lower effective tiller production rate when compared with more aged seedlings. This might be due to the production of secondary and tertiary tillers in the main 
field by low aged tillers which are incapable for production of panicle. The production of secondary and tertiary tillers in the main field will not develop into their full potential and will not able to compete with tillers formed by healthy seedlings of appropriate aged seedlings. Increased grain and straw yield due to planting of four weeks old seedlings was also reported by (Bozorgi et al., 2011).

Table 1: Yield attributes, grain, straw yield and harvest index, nitrogen uptake by the plant of machine transplanted rice as influenced by age and number of seedlings

\begin{tabular}{|c|c|c|c|c|c|c|c|}
\hline \multirow[t]{2}{*}{ Treatments } & \multicolumn{4}{|c|}{ Yield attributes } & \multicolumn{3}{|c|}{ Yield $\left(\mathrm{t} \mathrm{ha}^{-1)}\right.$} \\
\hline & No. of panicles $\mathrm{m}^{-2}$ & No. of grains panicle ${ }^{-1}$ & Filling $\%$ & Test wt. (g) & Grain & Straw & $\mathrm{HI}$ \\
\hline \multicolumn{8}{|c|}{ Main treatments $(\mathrm{A})$} \\
\hline$A_{1}$ & 352.45 & 101.25 & 84.67 & 17.19 & 4.80 & 6.00 & 0.45 \\
\hline $\mathrm{A}_{2}$ & 378.22 & 107.00 & 88.01 & 18.29 & 5.10 & 6.34 & 0.45 \\
\hline $\mathrm{A}_{3}$ & 358.11 & 103.04 & 86.63 & 17.65 & 4.89 & 6.12 & 0.45 \\
\hline $\mathrm{SEm} \pm$ & 4.90 & 0.93 & 0.63 & 0.20 & 0.057 & 0.063 & 0.00 \\
\hline $\mathrm{CD}(p=0.05)$ & 19.24 & 3.65 & 2.47 & 0.80 & 0.226 & 0.247 & NS \\
\hline \multicolumn{8}{|c|}{ Sub treatments $(\mathrm{N})$} \\
\hline $\mathrm{N}_{1}$ & 401.78 & 113.62 & 91.68 & 18.52 & 5.33 & 6.59 & 0.45 \\
\hline $\mathrm{N}_{2}$ & 361.67 & 101.20 & 86.25 & 17.74 & 4.87 & 6.13 & 0.44 \\
\hline $\mathrm{N}_{3}$ & 325.33 & 96.45 & 81.88 & 16.87 & 4.60 & 5.74 & 0.45 \\
\hline $\mathrm{SEm} \pm$ & 9.37 & 1.17 & 1.14 & 0.16 & 0.07 & 0.09 & 0.00 \\
\hline $\mathrm{CD}(p=0.05)$ & 36.80 & 4.61 & 4.47 & 0.64 & 0.26 & 0.33 & NS \\
\hline \multicolumn{8}{|c|}{ Interaction $(\mathrm{A} \times \mathrm{N})$} \\
\hline $\mathrm{A}_{1} \mathrm{~N}_{1}$ & 387.17 & 109.33 & 89.71 & 17.95 & 5.12 & 6.44 & 0.44 \\
\hline $\mathrm{A}_{1} \mathrm{~N}_{2}$ & 424.67 & 119.72 & 92.93 & 19.15 & 5.62 & 6.77 & 0.46 \\
\hline $\mathrm{A}_{1} \mathrm{~N}_{3}$ & 393.50 & 111.82 & 92.38 & 18.46 & 5.26 & 6.54 & 0.45 \\
\hline $\mathrm{A}_{2} \mathrm{~N}_{1}$ & 351.34 & 99.02 & 84.36 & 17.09 & 4.77 & 5.99 & 0.45 \\
\hline $\mathrm{A}_{2} \mathrm{~N}_{2}$ & 372.00 & 103.75 & 87.57 & 18.43 & 4.97 & 6.26 & 0.45 \\
\hline $\mathrm{A}_{2} \mathrm{~N}_{3}$ & 361.67 & 100.83 & 86.84 & 17.70 & 4.87 & 6.13 & 0.44 \\
\hline $\mathrm{A}_{3} \mathrm{~N}_{1}$ & 318.84 & 95.39 & 79.95 & 16.54 & 4.53 & 5.56 & 0.45 \\
\hline $\mathrm{A}_{3} \mathrm{~N}_{2}$ & 338.00 & 97.52 & 83.52 & 17.30 & 4.72 & 5.97 & 0.44 \\
\hline $\mathrm{A}_{3} \mathrm{~N}_{3}$ & 319.17 & 96.45 & 82.17 & 16.77 & 4.54 & 5.69 & 0.45 \\
\hline $\mathrm{SEm} \pm$ & 9.84 & 2.76 & 1.49 & 0.49 & 0.10 & 0.14 & 0.01 \\
\hline $\mathrm{CD}(p=0.05)$ & NS & NS & NS & NS & NS & NS & NS \\
\hline
\end{tabular}

NS: Non-significant; $A_{1}, A_{2}, A_{3}: 20,25,30$ days old seedlings, respectively; $\mathrm{N}_{1}, \mathrm{~N}_{2}, \mathrm{~N}_{3}: 3-4,5-6,7-8$ seedlings hill-1 ${ }^{-1}$, respectively

Resulted presented in Table 1 showed that higher number of panicles $\left(401.78 \mathrm{~m}^{2}\right)$, number of grains panicle ${ }^{-1}(113.67)$, filling \% (91.68), test weight (18.52), grain yield (5.33 t $\left.\mathrm{ha}^{-1}\right)$ and straw $\left(6.59 \mathrm{tha}^{-1}\right)$ was observed with planting of $3-4$ seedlings hill-1 as compared to planting of 7-8 seedlings hill-1 ${ }^{-1}$. However, it was followed by planting of 5-6 seedlings hill- ${ }^{-1}$. This may be due to healthy and efficient individual plant growth at lesser seedling density. The higher yield with low seedling density might be due to higher percentage of productive total tillers and more interception of light. At lower light intensity, there would not be any overlapping of leaves, so majority of the leaves will get the solar radiation. Also, grain filling which is the process of remobilization from stored reserves, particularly from stem, leaves, and from current photosynthesis. So, it may be inferred that the effectiveness of grain filling is decided by the conditions of particular tiller. Hence, planting of fewer seedlings resulted in higher grain yield (Rasool et al., 2013). Similar results was also reported by Maiti and Bhattacharya (2011).

\subsection{Nutrient uptake and availability}

\subsubsection{Age of seedlings}

Significant response was noticed by rice crop due to planting of different aged seedlings. Pooled data indicated that planting 
of twenty five days old seedling recorded significantly higher nitrogen uptake by the grain (6.93\%), straw (4.03\%) and total nitrogen uptake by the plant $(6.90 \%)(68.06,47.46$ and 115.52 $\mathrm{kg} \mathrm{ha}^{-1}$, respectively) (Table 2), uptake of phosphorous by grain $(4.90 \%)$, straw (5.85\%), and total phosphorous uptake by the plant $(5.06 \%),\left(24.06,13.20\right.$ and $37.26 \mathrm{~kg} \mathrm{ha}^{-1}$, respectively) and uptake of potash by grain $(7.55 \%)$, straw $(6.94 \%)$, and total potash uptake by the plant $(7.08 \%),(20.66,57.19$ and $77.85 \mathrm{~kg} \mathrm{ha}^{-1}$, respectively) over planting of twenty days old seedling. Nutrient uptake by rice is a product of concentration of nutrients in grain, grain yield, straw and straw yield. Perhaps profuse and robust root system due to early seedling vigour might have facilitated greater ability to mobilize more nutrients, concomitant higher absorption and translocation of nutrients and a well-developed and healthy root system play an important role in uptake and translocation of nutrients from the soil coupled with profuse and robust root system developed due to seedling vigour might have facilitated greater ability of absorption and translocation of major nutrients like $\mathrm{N}, \mathrm{P}$ and $\mathrm{K}$ which in turn have contributed for higher yield (Uphoff, 2005; Naidu et al., 2013). Planting of twenty days old seedlings recorded significantly higher soil available nitrogen, phosphorous and potassium $(241.55,51.05$ and $352.80 \mathrm{~kg}$ $\mathrm{ha}^{-1}$, respectively) and the same perhaps may be due to lower grain and straw yield and hence lower nitrogen uptake in this treatment led to more residual soil available nitrogen, phosphorous and potassium. Due to non-active uptake by the twenty days old seedlings all the major nutrients were remained in the soil as residual due to improper nutrient interaction.

\subsubsection{Number of seedlings hill-1}

Number of seedlings planted per hill also noticed significant

Table 2: Nitrogen, phosphorous \& potassium uptake by the grain, straw \& total uptake and available soil nutrients by the machine transplanted rice as influenced by age and number of seedlings (Pooled data of two years)

\begin{tabular}{|c|c|c|c|c|c|c|c|c|c|c|c|c|}
\hline \multirow[t]{2}{*}{ Treatments } & \multicolumn{3}{|c|}{$\begin{array}{l}\text { Nitrogen uptake } \\
\quad\left(\mathrm{kg} \mathrm{ha}^{-1}\right)\end{array}$} & \multicolumn{3}{|c|}{$\begin{array}{c}\text { Phosphorous uptake } \\
\left(\mathrm{kg} \mathrm{ha}^{-1}\right)\end{array}$} & \multicolumn{3}{|c|}{$\begin{array}{l}\text { Potassium uptake } \\
\left(\mathrm{kg} \mathrm{ha}^{-1}\right)\end{array}$} & \multicolumn{3}{|c|}{$\begin{array}{c}\text { Available nutrients } \\
\qquad\left(\mathrm{kg} \mathrm{ha}^{-1}\right)\end{array}$} \\
\hline & Grain & Straw & Total & Grain & Straw & Total & Grain & Straw & Total & $\mathrm{N}$ & $\mathrm{P}_{2} \mathrm{O}_{5}$ & $\mathrm{~K}_{2} \mathrm{O}$ \\
\hline \multicolumn{13}{|c|}{ Main treatments $(\mathrm{A})$} \\
\hline $\mathrm{A}_{1}$ & 63.65 & 44.45 & 108.09 & 22.94 & 12.47 & 35.41 & 19.21 & 53.48 & 72.70 & 241.55 & 51.05 & 352.80 \\
\hline $\mathrm{A}_{2}$ & 68.06 & 47.46 & 115.52 & 24.06 & 13.20 & 37.26 & 20.66 & 57.19 & 77.85 & 236.30 & 47.80 & 345.30 \\
\hline $\mathrm{A}_{3}$ & 66.22 & 46.47 & 112.67 & 23.34 & 12.84 & 36.18 & 19.84 & 54.78 & 74.61 & 238.65 & 49.80 & 347.65 \\
\hline $\mathrm{SEm} \pm$ & 0.68 & 0.46 & 1.24 & 0.21 & 0.13 & 0.33 & 0.28 & 0.68 & 0.93 & 0.89 & 0.56 & 1.38 \\
\hline $\mathrm{CD}(p=0.05)$ & 2.66 & 1.82 & 4.86 & 0.82 & 0.50 & 1.31 & 1.08 & 2.66 & 3.64 & 3.49 & 2.21 & 5.40 \\
\hline \multicolumn{13}{|c|}{ Sub treatments $(\mathrm{N})$} \\
\hline $\mathrm{N}_{1}$ & 71.67 & 50.96 & 122.62 & 25.31 & 13.73 & 39.03 & 21.78 & 59.67 & 81.45 & 230.95 & 45.35 & 342.95 \\
\hline $\mathrm{N}_{2}$ & 64.80 & 45.28 & 110.10 & 23.32 & 12.72 & 36.04 & 19.79 & 55.29 & 75.08 & 237.75 & 50.35 & 348.20 \\
\hline $\mathrm{N}_{3}$ & 61.45 & 42.14 & 103.60 & 21.72 & 12.05 & 33.77 & 18.16 & 50.48 & 68.64 & 247.85 & 53.00 & 354.55 \\
\hline $\mathrm{SEm} \pm$ & 0.76 & 0.72 & 1.46 & 0.30 & 0.15 & 0.42 & 0.33 & 1.16 & 1.30 & 1.45 & 1.13 & 1.05 \\
\hline $\mathrm{CD}(p=0.05)$ & 2.98 & 2.81 & 5.74 & 1.30 & 0.61 & 1.64 & 1.29 & 4.57 & 5.12 & 5.68 & 4.44 & 4.12 \\
\hline \multicolumn{13}{|c|}{ Interaction $(\mathrm{A} \times \mathrm{N})$} \\
\hline $\mathrm{A}_{1} \mathrm{~N}_{1}$ & 67.97 & 48.63 & 116.60 & 24.48 & 13.19 & 37.67 & 20.84 & & 78.79 & 244.05 & 51.60 & 352.45 \\
\hline $\mathrm{A}_{1} \mathrm{~N}_{2}$ & 74.89 & 54.07 & 128.95 & 26.08 & 14.23 & 40.30 & 22.56 & 61.91 & 84.48 & 251.55 & 54.35 & 357.85 \\
\hline $\mathrm{A}_{1} \mathrm{~N}_{3}$ & 72.15 & 50.18 & 122.33 & 25.36 & 13.77 & 39.13 & 21.93 & 59.15 & 81.07 & 247.90 & 53.05 & 353.40 \\
\hline $\mathrm{A}_{2} \mathrm{~N}_{1}$ & 63.15 & 43.86 & 107.01 & 22.76 & 12.34 & 35.10 & 18.99 & 53.82 & 72.81 & 235.45 & 49.10 & 345.50 \\
\hline $\mathrm{A}_{2} \mathrm{~N}_{2}$ & 67.35 & 46.86 & 114.21 & 23.98 & 13.07 & 37.04 & 20.69 & 56.72 & 77.41 & 240.55 & 51.35 & 352.20 \\
\hline $\mathrm{A}_{2} \mathrm{~N}_{3}$ & 63.90 & 45.13 & 109.03 & 23.21 & 12.75 & 35.96 & 19.68 & 55.35 & 75.03 & 237.30 & 50.60 & 346.95 \\
\hline $\mathrm{A}_{3} \mathrm{~N}_{1}$ & 59.82 & 40.88 & 100.69 & 21.59 & 11.88 & 33.47 & 17.81 & 48.68 & 66.49 & 229.35 & 42.80 & 337.90 \\
\hline $\mathrm{A}_{3} \mathrm{~N}_{2}$ & 61.94 & 41.45 & 103.39 & 22.11 & 12.30 & 34.40 & 18.75 & 52.93 & 71.67 & 232.60 & 47.50 & 348.20 \\
\hline $\mathrm{A}_{3} \mathrm{~N}_{3}$ & 62.60 & 44.09 & 106.70 & 21.46 & 11.99 & 33.44 & 17.91 & 49.83 & 67.74 & 230.90 & 45.85 & 342.59 \\
\hline $\mathrm{SEm} \pm$ & 0.85 & 1.22 & 0.1 .91 & 0.55 & 0.16 & 0.55 & 0.52 & 1.67 & 2.08 & 2.73 & 1.88 & 3.58 \\
\hline $\mathrm{CD}(p=0.05)$ & NS & NS & 2.88 & NS & $\mathrm{NS}$ & NS & $\mathrm{NS}$ & $\mathrm{NS}$ & $\mathrm{NS}$ & $\mathrm{NS}$ & $\mathrm{NS}$ & NS \\
\hline
\end{tabular}

NS: Non-significant; $A_{1}, A_{2}, A_{3}: 20,25,30$ days old seedlings, respectively; $N_{1}, N_{2}, N_{3}: 3-4,5-6,7-8$ seedlings hill $^{-1}$, respectively 
variation in the uptake of nutrients. Planting of 3-4 seedlings hill $^{-1}$ recorded significantly higher uptake of nitrogen (16.63, 20.93 and $18.40 \% \mathrm{ha}^{-1}$, respectively), phosphorous (16.53, 13.94 and $15.58 \% \mathrm{ha}^{-1}$, respectively) and potassium (19.93, 18.21 and $18.66 \% \mathrm{ha}^{-1}$, respectively) (Table 2 ) by grain, straw and total uptake over planting of 7-8 seedlings hill- ${ }^{-1}$. Planting of 7-8 seedlings hill ${ }^{-1}$ noticed significantly higher available nitrogen, phosphorous and potassium in soil after harvest $\left(247.85,53.00\right.$ and $354.55 \mathrm{~kg} \mathrm{ha}^{-1}$, respectively) over planting of 3-4 seedlings hill-1 ${ }^{-1}(230.95,45.35$ and $342.95 \mathrm{~kg}$ $\mathrm{ha}^{-1}$, respectively) obviously due to lower uptake of nutrients and lesser grain and straw yield (Naidu et al., 2013).

Significant interaction effect was noticed with respect to total uptake of nitrogen. Planting of twenty days old seedling and planting of 5-6 seedlings hill ${ }^{-1}$ recorded significantly higher total uptake of nitrogen (128.95) over rest of the treatments.

\section{Conclusion}

Planting of twenty five old and 3-4 seedlings hill-1 recorded higher nutrient uptake grain and straw yield when compared to other two ages and number of seedlings hill'-1, where as Planting of twenty days old and 7-8 seedlings hill-1 recorded significantly higher soil available nitrogen, phosphorous and potassium. Planting of twenty-five days old and 3-4 seedlings hill $^{-1}$ was found optimum for transplanting with self-propelled mechanical transplanter.

\section{References}

Anonymous, 2008. Importance and nutritional value of rice in Asian regions. The Hindu Survey of Indian Agriculture, 23-26.

FAO, 2015. World acreage and production of rice-Annual report. www.statista.com.

Anonymous, 2015. Agricultural Statistics at glance, Directorate of economics and statistics. Department of Agriculture and Co-operation, Ministry of Agriculture, Government of India. 34-37.

Aswini, G.K., Swain, S., Debaraj, B., 2009. Effect of seedling age on performance of rice transplanter. Agricultural Mechanization in Asia, Africa and Latin America 40, 41-46.

Behera, B.K., 2000. Investigation on puddle soil characteristics in relation to performance of self propelled rice transplanter. Un-published Ph.D. Thesis G.B. Pant University of Ag. and Tech., Pantnagar, UP.

Bozorgi, H.R., Amin, Faji., Khasravi, Danesh., Abdolkarim, K., Ebrahim, A., Freshieh, T., 2011. Effect of plant density on yield and yield component of rice. World Applied Science Journal 12, 2053-2057.
Hossain, M.S., Mamun, A.A., Basak, R., Newaj, M.N., Anam, M.K., 2003. Effect of cultivar and spacing on weed infestation and performance of transplanted aman rice in Bangladesh. Pakistan Journal of Agronomy 2(3), 169-178.

Jackson, M.L., 1967. Soil Chemical Analysis. Prentice Hall of India Private Limited, New Delhi, 498.

Jackson, M.L., 1973. Soil Chemical Analysis. Prentice-Hall of India, Pvt. Ltd., New Delhi, 121-125.

Kim, S.S., Kim, B.K., Choi, M.G., Back, M.H., Choi, W.Y., Lee, S.Y., 1999. Effect of seedling age on growth and yield of machine transplanted rice in southern plain region. Korean Journal of Crop Science 44, 122-128

Maiti, P.K., Bhattacharya, B., 2011. Effect of seedling rate and number of seedlings hill-1 on the growth and yield of hybrid rice (Oryza sativa L.) grown in dry (boro) season. Crop Research 42, 18-22.

Naidu, G.J., Rao, K.T., Rao, A.U., Reddy, D.S., 2013. Age of seedling and planting pattern on grain yield, protein content, NPK uptake and post harvest nutrient status of rice under SRI. Journal of Academia and Industrial Research 2, 334-337.

Olsen, S.R., Cole, C.L., Watanabe, F.S., Deaw, D.A., 1954. Estimation of available phosphorous in soils by extraction with sodium bicarbonate. United States Departments of Agriculture circular, 939.

Rao, M.V., Pradhan, S.V., 1973. Cultivation practice. Rice production manual, ICAR, 71-95.

Rasool, F., Habib, R., Bhat, M.I., 2013. Agronomic evaluation of rice (Oryza sativa L.) for plant spacing and seedlings per hill under temperate conditions. Pakistan Journal of Agricultural Sciences 9, 169-172.

Singh, G., Sharma, T.R., Bockhop, C.W., 1985. Field performance evaluation of a manual rice transplanter. Journal of Agriculture Engineering Research 32, 259-268.

Subbaiah, B.V., Asija, G.L., 1956. Rapid procedure for determination of available nitrogen in soils. Current Science 31, 196.

Upholf, N., 2005. On-farm evaluation of SRI in Tamiraparani Command area of Tamil Nadu, India. Available from http://ciifad.cornell.edu/sri/. Accessed in June 2005.

Tadesse, F.T., Declasse, N.R., Bayou, W., Gebeyehu, S., 2013. Effect of transplanting on terminal moisture stress, growth and yield of rainfed lowland rice. Research Journal of Agriculture Environment and Management. 2(4), 117-129. 